\title{
Comparative chemical composition of armed saltbush and fourwing saltbush
}

\author{
ANDRES GARZA, JR., AND TIMOTHY E. FULBRIGHT
}

Abstract

Armed saltbush [Atriplex acanthocarpa (Torr.) Wats.] and fourwing saltbush [A. canescens (Pursh) Nutt.] are browsed by livestock and white-tailed deer (Odocoileus virginianus Raf.). The objective of this study was to compare the chemical composition of these $\mathbf{2}$ shrubs growing together in south Texas. Leaves and stems from the outer $5 \mathrm{~cm}$ of current year's growth of each species were randomly collected from each of 5 stands in November 1985 and February, May, and August 1986. Samples were analyzed for crude protein (CP), calcium, potassium (K), magnesium (Mg), sodium (Na), phosphorus ( $P$ ), and in vitro organic matter digestibility (IVOMD). Height and standing crop were also determined. Crude protein of armed saltbush leaves ranged from $32 \%$ in February to $19 \%$ in August. Fourwing saltbush leaf CP ranged from $24 \%$ in February to $12 \%$ in August. Armed saltbush leaves and stems generally had greater $\mathbf{P}$ concentrations than fourwing saltbush. Calcium, $K$, and $M g$ concentrations and leaf IVOMD of the 2 species were similar. Fourwing saltbush had lower Na concentrations and greater leaf standing crop than armed saltbush. Laboratorydetermined values suggest that both species may provide nutritious browse for cattle and deer on saline rangeland.

Key Words: Atriplex acanthocarpa, Atriplex canescens, browse, crude protein, in vitro dizestibility

Saltbushes (Atriplex sp.) are found in semiarid environments in the western United States, the Middle East, Australia, Africa, and Siberia (Davis 1981), and many species are valued as forage for domestic and wild herbivores. Two saltbushes native to North America are armed saltbush [A. acanthocarpa (Torr.) Wats.] and fourwing saltbush [A. canescens (Pursh) Nutt.].

Armed saltbush grows on saline soils from south Texas west to Arizona (Vines 1960, Jones 1982). The half-shrub is palatable to cattle (Bos. sp.) and white-tailed deer (Odocoileus virginianus Raf.) (Vines 1960, J.H. Everitt, USDA-ARS, Weslaco, Texas, pers. commun.) and has potential for use in revegetation of saline rangeland (T. Gonzalez, SCS, Laredo, Texas, pers. commun.). Fourwing saltbush occurs from Canada south to Mexico and west to southern California (Vines 1960). The shrub is considered valuable browse for cattle, sheep, and deer (Stubbendieck et al. 1982) and is widely used in revegetation.

The chemical composition of fourwing and numerous other saltbushes is well documented (Beadle et al. 1957, Pieper et al. 1959, Chatterton et al. 1971, Cordova and Wallace 1975, Khalil et al. 1986, Petersen et al. 1987). However, the chemical composition of armed saltbush has not been documented. The objective of this study was to compare the chemical composition of armed saltbush with that of fourwing saltbush.

\section{Materials and Methods}

The study was conducted on the Hinnant-Fulbright Ranch in northeastern Zapata County, Texas. Study sites were on a rolling hardland range site. Soils are Maverick clay (fine, montmorillo

\footnotetext{
Authors are research associate and associate professor, Caesar Kleberg Wildlife Research Institute, Campus Box 218, Texas A\&I University, Kingsville, Texas 78363. Research was funded by the Caesar Kleberg Foundation for Wildlife Conservation. Authors thank Robert Fulbright for access to his land and Ramesh Chamala for assistance in the laboratory.

Manuscript accepted 16 May 1988.
}

nitic, hyperthermic Ustollic Camborthid). Electrical conductivity of these soils exceeds $4 \mathrm{dS} \mathrm{m}^{-1}$ in the surface $25 \mathrm{~cm}^{2}$ and $12 \mathrm{dS} \mathrm{m}^{-1}$ in the 25 to $50 \mathrm{~cm}$ depth (Fanning et al. 1965). Topography is gently rolling with less than $3 \%$ slope. Hot summers and short, mild winters characterize the climate. Mean annual precipitation is about $38 \mathrm{~cm}$, with peaks in May and September (Fulbright 1985). Associated woody vegetation includes honey mesquite (Prosopis glandulosa Torr.), creosotebush (Larrea divaricata Cav.), blackbrush (Acacia rigidula Benth.), guajillo (Acacia berlandieri Benth.), guayacan [Porliera angustifolia (Engelm.) Gray], leatherstem (Jatropha dioica Sesse ex Cerv.), allthorn (Koeberlinia spinosa Zucc.), vine ephedra (Ephedra antisyphlitica Berl. ex C.A. Meyer), allthorn goatbush [Castela texana (T.\& G.) Rose], trecul yucca (Yucca treculeana Carriere), lotebush [Condalia obtusifolia (Hook.) Weberb.], and knifeleaf condalia (Condalia spathulata Gray). Associated herbaceous vegetation includes berlandier nettlespurge (Jatropha cathartica Teran \& Berl.), Texas varilla (Varillis texana Gray), threeawns (Aristida sp.), and multiflowered false-rhodesgrass [Chloris pluriflora (Fourn.) Clayton].

Five stands supporting both saltbush species were sampled. Each stand was a replication (block) in statistical analyses since samples were collected, dried, and chemically analyzed separately for each stand. Samples of the outer $5 \mathrm{~cm}$ of current year's growth from at least 4 randomly selected individuals of each species were collected within each stand in November 1985, and February, May, and August 1986. Samples were dried at $40^{\circ} \mathrm{C}$ to a constant weight, separated into stems and leaves, and ground in a Wiley mill to pass a $1-\mathrm{mm}$ screen. Dry and organic matter contents were determined following AOAC (1980) procedures. Crude protein (CP) $(\% \mathrm{~N} \times 6.25)$ was determined by the micro-Kjeldahl procedure (AOAC 1980) and is reported on an organic-matter basis. Mineral analyses were done by the Soil Testing Laboratory, Texas Agricultural Extension Service, Texas A\&M University, College Station. Atomic absorption spectrophotometry was used to determine calcium $(\mathrm{Ca})$ and magnesium $(\mathbf{M g})$ concentrations. Sodium (Na) and potassium (K) levels were determined with flame photometry, and phosphorus $(\mathrm{P})$ content was determined colorimetrically (Parkinson and Allen 1975). All assays were done in duplicate and values are reported on a dry matter basis.

In vitro organic matter digestibility (IVOMD) was determined by the procedure of Tilley and Terry (1963). Rumen inocula were obtained from a Jersey cow fed a high quality roughage diet. Forages with known in vivo digestibilities were included in each digestion batch to standardize results.

Height and standing crop of armed and fourwing saltbush were determined in August 1986. Height of 20 randomly selected, mature plants of each species was measured in each of 4 stands. Plants were then cut at ground level and dried at $55^{\circ} \mathrm{C}$ to a constant weight, separated into leaves and non-leaf material (stems, branches, trunks) and weighed. Density of armed and fourwing saltbush was estimated in April, 1988 by counting the number of individuals rooted in 6 randomly placed 2.44 by $15.25-\mathrm{m}$ plots in each of 4 stands.

Bimonthly rainfall data from the Hinnant-Fulbright Ranch for 1985 and 1986 were obtained from C.W. Hanselka, Texas A\&M University, Corpus Christi, Texas.

Chemical composition and digestibility data were analyzed by 
Table 1. Temporal trends in mean percent crude protein (CP), calcium (Ca), phocphorus (P), codium (Na), potascium (K), magnedum (Mg), and in vitro organic matter digeatibility (IVOMD) of amed and fourning alibuah leaves and ateme, Zapata County, Texas, $1995-1936$.

\begin{tabular}{|c|c|c|c|c|c|c|c|c|}
\hline \multirow[b]{3}{*}{ Variable and plant part } & \multicolumn{8}{|c|}{ Sampling date and species } \\
\hline & \multicolumn{2}{|c|}{ November 1985} & \multicolumn{2}{|c|}{ February 1986} & \multicolumn{2}{|c|}{ May 1968} & \multicolumn{2}{|c|}{ August 1986} \\
\hline & Armed & Fourwing & Armed & Fourwing & Armed & Fourwing & Armed & Fourwing \\
\hline \multicolumn{9}{|l|}{$\overline{\mathrm{CP}}$} \\
\hline $\begin{array}{l}\text { Leaves } \\
\text { Stems }\end{array}$ & $\begin{array}{c}20.1 \mathrm{a}^{\mathrm{l}} \\
9.1 \mathrm{~b}\end{array}$ & $\begin{array}{r}18.9 \mathrm{a} \\
8.4 \mathrm{~b}\end{array}$ & $\begin{array}{l}32.4 a \\
20.1 b\end{array}$ & $\begin{array}{l}23.7 \mathrm{~b} \\
14.7 \mathrm{c}\end{array}$ & $\begin{array}{l}24.6 \mathrm{a} \\
14.3 \mathrm{c}\end{array}$ & $\begin{array}{l}18.5 b \\
10.1 d\end{array}$ & $\begin{array}{l}18.8 a \\
10.9 b\end{array}$ & $\begin{array}{r}11.6 b \\
4.6 c\end{array}$ \\
\hline $\mathrm{Ca}$ & & & & & & & & \\
\hline $\begin{array}{l}\text { Leaves } \\
\text { Stems }\end{array}$ & $\begin{array}{l}1.8 \mathrm{a} \\
1.0 \mathrm{~b}\end{array}$ & $\begin{array}{l}1.6 \mathrm{a} \\
0.7 \mathrm{c}\end{array}$ & $\begin{array}{l}1.3 \mathrm{a} \\
1.3 \mathrm{a}\end{array}$ & $\begin{array}{l}1.8 \mathrm{a} \\
1.2 \mathrm{a}\end{array}$ & $\begin{array}{l}1.3 \mathrm{ab} \\
1.4 \mathrm{ab}\end{array}$ & $\begin{array}{l}1.5 \mathrm{a} \\
1.1 \mathrm{~b}\end{array}$ & $\begin{array}{l}1.4 \mathrm{a} \\
1.3 \mathrm{ab}\end{array}$ & $\begin{array}{l}1.3 \mathrm{ab} \\
1.0 \mathrm{~b}\end{array}$ \\
\hline $\begin{array}{l}\text { Leaves } \\
\text { Stems } \\
\text { Mg }\end{array}$ & $\begin{array}{l}1.6 \mathrm{ab} \\
1.3 \mathrm{~b}\end{array}$ & $\begin{array}{l}2.3 a \\
1.4 b\end{array}$ & $\begin{array}{l}2.7 a \\
2.1 a\end{array}$ & $\begin{array}{l}2.8 \mathrm{a} \\
2.2 \mathrm{a}\end{array}$ & $\begin{array}{l}2.6 \mathrm{a} \\
2.6 \mathrm{a}\end{array}$ & $\begin{array}{l}2.7 \mathrm{a} \\
2.4 \mathrm{a}\end{array}$ & $\begin{array}{l}2.3 a b \\
2.1 a b\end{array}$ & $\begin{array}{l}2.5 \mathrm{a} \\
1.9 \mathrm{~b}\end{array}$ \\
\hline $\begin{array}{l}\text { Leaves } \\
\text { Stems } \\
\text { Na }\end{array}$ & $\begin{array}{l}1.3 \mathrm{a} \\
0.7 \mathrm{~b}\end{array}$ & $\begin{array}{l}1.0 \mathrm{ab} \\
0.3 \mathrm{c}\end{array}$ & $\begin{array}{l}0.9 \mathrm{ab} \\
0.6 \mathrm{~b}\end{array}$ & $\begin{array}{l}1.1 \mathrm{a} \\
0.5 \mathrm{~b}\end{array}$ & $\begin{array}{l}0.8 \mathrm{a} \\
0.4 \mathrm{~b}\end{array}$ & $\begin{array}{l}0.8 \mathrm{a} \\
0.4 \mathrm{~b}\end{array}$ & $\begin{array}{l}0.8 \mathrm{a} \\
0.4 \mathrm{~b}\end{array}$ & $\begin{array}{l}0.7 \mathrm{a} \\
0.3 \mathrm{~b}\end{array}$ \\
\hline $\begin{array}{l}\text { Leaves } \\
\text { Stems }\end{array}$ & $\begin{array}{l}7.7 \mathrm{a} \\
3.3 \mathrm{~b}\end{array}$ & $\begin{array}{l}2.7 \mathrm{~b} \\
1.1 \mathrm{c}\end{array}$ & $\begin{array}{l}9.4 a \\
4.4 b\end{array}$ & $\begin{array}{l}2.6 \mathrm{c} \\
1.4 \mathrm{~d}\end{array}$ & $\begin{array}{l}9.8 \mathrm{a} \\
5.4 \mathrm{~b}\end{array}$ & $\begin{array}{l}2.2 \mathrm{c} \\
1.3 \mathrm{c}\end{array}$ & $\begin{array}{r}10.5 \mathrm{a} \\
5.4 \mathrm{~b}\end{array}$ & $\begin{array}{l}2.7 \mathrm{c} \\
1.1 \mathrm{~d}\end{array}$ \\
\hline $\begin{array}{l}\text { Leaves } \\
\text { Stems } \\
\text { IVOMD }\end{array}$ & $\begin{array}{l}0.23 a \\
0.17 a\end{array}$ & $\begin{array}{l}0.19 a \\
0.09 b\end{array}$ & $\begin{array}{l}0.29 a \\
0.28 a\end{array}$ & $\begin{array}{l}0.23 a b \\
0.16 b\end{array}$ & $\begin{array}{l}0.29 \mathrm{a} \\
0.24 \mathrm{ab}\end{array}$ & $\begin{array}{l}0.21 b \\
0.10 c\end{array}$ & $\begin{array}{l}0.23 a \\
0.20 a b\end{array}$ & $\begin{array}{l}0.18 b \\
0.07 c\end{array}$ \\
\hline $\begin{array}{l}\text { Leaves } \\
\text { Stems }\end{array}$ & $\begin{array}{l}68.0 \mathrm{a} \\
34.2 \mathrm{~b}\end{array}$ & $\begin{array}{l}66.2 \mathrm{a} \\
32.0 \mathrm{~b}\end{array}$ & $\begin{array}{l}62.6 \mathrm{ab} \\
59.1 \mathrm{~b}\end{array}$ & $\begin{array}{l}71.0 \mathrm{a} \\
45.4 \mathrm{c}\end{array}$ & $\begin{array}{l}66.6 \mathrm{a} \\
47.7 \mathrm{~b}\end{array}$ & $\begin{array}{l}62.5 a \\
36.9 c\end{array}$ & $\begin{array}{l}58.2 \mathrm{~b} \\
41.5 \mathrm{c}\end{array}$ & $\begin{array}{l}61.7 \mathrm{a} \\
31.3 \mathrm{~d}\end{array}$ \\
\hline
\end{tabular}

'Means for a variable within a sampling date followed by the same letter are not significantly different at the 0.05 level according to Tukey's test. Leaves were compa red to stems within a sampling date.

analysis of variance using a randomized complete-block experimental design with stands as blocks and sampling dates as a split in time. The sampling date $X$ species and plant part interaction was significant $(P<0.05)$ for all variables except $P$ and $K$, thus a separate analysis of variance was done for each sampling date to compare species and plant part means. Tukey's test was used to separate means, where appropriate (Snedecor and Cochran 1967). Height and standing crop data were analyzed using $t$-tests. Inferences based on the results of this study are restricted to the study area.

\section{Results and Discussion}

Rainfall during August 1985 to August 1986 was $29.2 \mathrm{~cm}$ (Fig. 1). Rainfall was above average in June-July 1985 and 1986, but was below average during the remainder of the study.

Crude protein concentration of armed saltbush leaves and stems exceeded that of fourwing saltbush on all sampling dates except November 1985 (Table 1). Crude protein of armed saltbush leaves ranged from 32\% in February to $19 \%$ in August while that of fourwing saltbush leaves ranged from $24 \%$ in February to $12 \%$ in August. Crude protein values for fourwing saltbush were similar to

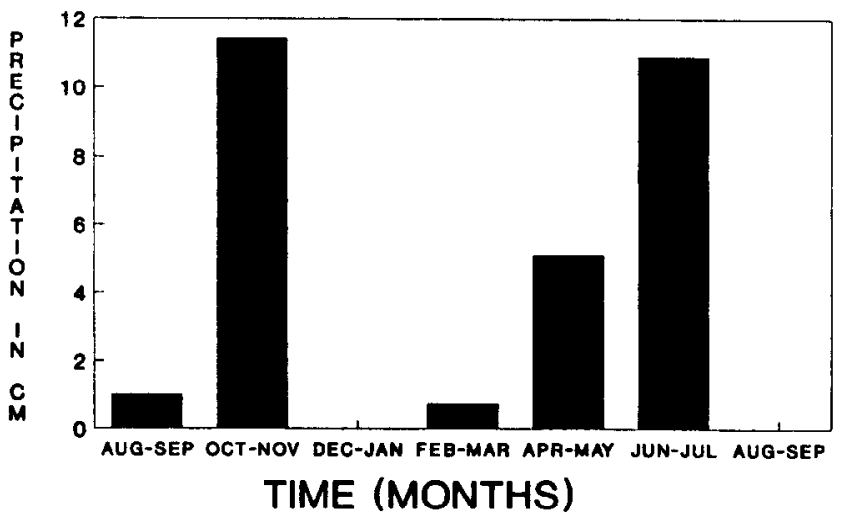

Fig. 1. Bimonthly precipitation (cm) from August, 1985 through September, 1986 on the Hinnant-Fulbright Ranch, Zapata County, Texas. those reported for 4 fourwing ecotypes from west Texas (Petersen et al. 1987).

Calcium, $\mathbf{K}$, and $\mathrm{Mg}$ levels were similar in armed and fourwing saltbush leaves and stems on all sampling dates except November (Table 1). In November, levels of $\mathrm{Ca}$ and $\mathrm{Mg}$ were higher in armed than in fourwing saltbush stems.

Sodium levels in armed saltbush leaves ranged from 7.7 to $10.5 \%$, compared to 2.2 to $2.7 \%$ for fourwing saltbush leaves (Table 1). Armed saltbush stems were also higher in $\mathrm{Na}$ than fourwing saltbush stems on all sampling dates. Other researchers have reported lower $\mathrm{Na}$ concentrations in fourwing saltbush in comparison to other Atriplex species (Wallace et al. 1973, Smit and Jacobs 1978, Khalil et al. 1986).

Levels of $\mathrm{Na}$ in fourwing saltbush were higher than the $0.21 \%$ in leaves reported by Khalil et al. (1986), whereas $K$ levels were much lower than the $6.06 \%$ they reported. Differences between our results and those of Khalil et al. (1986) possibly resulted because distinct biotypes of fourwing saltbush exist with regard to $\mathrm{Na}$ and $K$ accumulation (Richardson 1982). Certain biotypes tend to exclude $\mathrm{Na}$ and absorb large amounts of $\mathrm{K}$, while others accumulate $\mathrm{Na}$ and absorb less $\mathrm{K}$. Also, differences in soil $\mathrm{Na}$ content probably caused results to differ between studies.

Phosphorus levels were similar in armed and fourwing saltbush leaves in November and February and were higher in armed than in fourwing leaves in May and August (Table 1). Armed saltbush

Table 2. Mean height (em), standing crop/plant (s) of leaves and woody material, and total standing crop/plant ( $B$ ) of armed and fourwing saltbuah in Auguat 1936, Zapats County, Texes.

\begin{tabular}{lcc}
\hline \hline & \multicolumn{2}{c}{ Saltbush species } \\
\cline { 2 - 3 } Characteristic & Armed & Fourwing \\
\hline Height & 65 & $95^{* *}$ \\
Leaf standing crop/plant & 40 & $114^{*}$ \\
Woody material standing crop/plant & 146 & $920^{* *}$ \\
Total standing crop/plant & 186 & $1,034^{* *}$ \\
\hline
\end{tabular}

*** Significant difference between species at the 0.05 or 0.01 level, respectively. 
leaves had $P$ levels ranging from 0.23 to $0.29 \%$, compared to 0.18 to $0.23 \%$ for fourwing saltbush leaves. Armed saltbush stems had higher $P$ concentrations than fourwing saltbush stems on all sampling dates.

The IVOMD of fourwing saltbush leaves exceeded that of armed saltbush in August, but digestibility of leaves of the 2 species was similar on other sampling dates (Table 1). Armed saltbush stems were more digestible than fourwing saltbush stems on all sampling dates except November, when digestibility was similar. Lower digestibility of fourwing stems was expected because they are woodier than stems of armed saltbush.

Fourwing saltbush plants were $46 \%$ taller than armed saltbush (Table 2). Although leaf standing crop of fourwing saltbush was almost triple that of armed saltbush, the leaf:stem ratio was higher for armed saltbush than for fourwing (1:3.7 and 1:8.1, respectively). Total standing crop/plant of fourwing was 5.6 times higher than armed saltbush. Estimated mean density of armed saltbush was $1,648 \pm 921$ plants ha ${ }^{-1}(\bar{x} \pm S E, n=4)$ compared to $2,836 \pm$ 1,194 plants $\mathrm{ha}^{-1}$ for fourwing saltbush.

These data suggest that fourwing and armed saltbush on saline rangeland may provide nutritious browse for cattle and deer. Research on animal performance while consuming these plants is needed to fully understand their importance to herbivores on saline rangeland in southern Texas. Results of laboratory analyses may be misleading because many shrubs contain secondary plant metabolites that may interfere with protein digestibility (Robbins et al. 1987). Further research is needed to determine if armed saltbush and fourwing saltbush contain secondary plant metabolites.

\section{Literature Cited}

AOAC. 1980. Official methods of analysis, 13th ed. Assoc. Off. Anal. Chem., Washington, D.C.

Beadle, N.C.W., R.D.B. Whalley, and J.B. Gibson. 1957. Studies in the halophytes II. Analytic data on the mineral constituents of three species of Atriplex and their accompanying soils in Australia. Ecology 38:340-344.
Chatterton, N.J., J.R. Goodin, C.M. MeKell, R.V. Parker, and J.M. Rible. 1971. Monthly variation in the chemical composition of desert saltbush. J. Range Manage. 24:37-40.

Cordova, F.J., and J. Wallace. 1975. Nutritive value of some browse and forb species. Proc. West. Sec. Amer. Soc. Anim. Sci. 26:160-162.

Davis, A.M. 1981. The oxalate, tannin, crude fiber, and crude protein composition of young plants of some Atriplex species. J. Range Manage. 34:329-331.

Fanning. C.D., C.M. Thompaon, and D. Iseacs. 1965. Properties of saline range soils of the Rio Grande Plain. J. Range Manage. 18:190-193.

Fulbright, R. 1985. Buffelgrass hay production, p. 30-34. In: Proc. Symp. on Buffelgrass: Adaptation, Management, and Forage Quality, 7 June 1988, Weslaco, Texas Agr. Exp. Sta., College Station.

Jones, F.B. 1982. Flora of the Texas Coastal Bend, 3rd edition. Welder Wildlife Foundation, Sinton, Texas.

Khalil, J.K., W.N. Sawaya, and S.Z. Hyder. 1986. Nutrient composition of Atriplex leaves grown in Saudi Arabia. J. Range Manage. 39:104-107.

Parkinson, J.A., and S.E. Allen. 1975. A wet oxidation procedure suitable for the determination of nitrogen and mineral nutrients in biological material. Comm. Soil Sci. and Plant Anal. 6:1-11.

Petersen, J.L., D.N. Ueckert, and R.L. Potter. 1987. Ecotypic variation in selected fourwing saltbush populations in western Texas. J. Range Manage. 40:361-366.

Pieper, R.D., C.W. Cook, and L.E. Harris. 1959. Effect of intensity of grazing upon nutritive content of the diet. J. Anim. Sci. 18:1031-1037.

Richardson, S.G. 1982. High and low sodium biotypes of fourwing saltbush: Their responses to sodium and potassium in retorted oil shale. J. Range Manage. 35:795-797.

Robbins, C.T., T.A. Hanley, A.E. Hagerman, O. Hjeljord, D.L. Baker, C.C. Schwartz, and W.W. Mautz. 1987. Role of tannins in defending plants against ruminants: Reduction in protein availability. Ecology 68:98-107.

Smit, C.J., and G.A. Jacobs. 1978. Chemical composition of four Atriplex species. Agroanimalia 10:1-5.

Snedecor, G.W., and W.G. Cochran. 1967. Statistical methods, 6th ed. Iowa State Univ. Press, Ames.

Stubbendieck, J., S.L. Hatch, and K.J. Kjar. 1982. North American range plants, 2nd ed. Univ. Nebraska Press, Lincoln.

Tilley, J.M.A., and R.A. Terry. 1963. A two-stage technique for the in vitro digestion of forage crops. J. Brit. Grassl. Soc. 18:104-111.

Vines, R.A. 1960. Trees, shrubs, and woody vines of the Southwest. Univ. Texas Press, Austin.

Wallace, A., E.M. Romney, and R.T. Mueller. 1973. Sodium relations in desert plants. I. Cation contents of some species from the Mojave and Great Basin Deserts. Soil Sci. 115:284-287. 